\title{
Proximate Analysis and Safety Profile of Farmed Edible Bird's Nest in Malaysia and Its Effect on Cancer Cells
}

\author{
Sin Nee Tan $\left(\mathbb{D},{ }^{1}\right.$ Dahiru Sani, ${ }^{1}$ Chee Woei Lim, ${ }^{1}$ Aini Ideris $(\mathbb{D})^{2}$ Johnson Stanslas $(\mathbb{D})^{1}$ \\ and Christopher Thiam Seong Lim (iD ${ }^{1}$ \\ ${ }^{1}$ Department of Medicine, Faculty of Medicine and Health Sciences, Universiti Putra Malaysia, Serdang, Malaysia \\ ${ }^{2}$ Faculty of Veterinary Medicine, Universiti Putra Malaysia, Serdang, Malaysia \\ Correspondence should be addressed to Christopher Thiam Seong Lim; drchrislim@gmail.com
}

Received 26 May 2019; Revised 18 August 2019; Accepted 6 November 2019; Published 21 January 2020

Academic Editor: Olumayokun A. Olajide

Copyright ( $\odot 2020$ Sin Nee Tan et al. This is an open access article distributed under the Creative Commons Attribution License, which permits unrestricted use, distribution, and reproduction in any medium, provided the original work is properly cited.

Edible bird's nest (EBN) which is solidified swiftlet's saliva contains high nutritional value. It is widely consumed in countries like Malaysia, Indonesia, and Thailand. However, previous proximate analysis of Malaysia EBN was not representative of all the regions in Malaysia. In recent years, safety issues such as high nitrate and nitrite contents, presence of heavy metal, adulteration, fungal infection, and cancer cell stimulation were associated with EBN. Hence, this study aimed to determine the proximate analysis, safety profile during normal weather and hazy periods, and its effect on cancer cells stimulation in Malaysia-farmed EBN. Seven raw cleaned EBN samples were sourced from 6 different regions in Malaysia. Proximate analysis and safety profile were performed using official AOCA methods and Malaysian Standard. High protein (53.03-56.37\%) and carbohydrate content (27.97-31.68\%) with an acceptable level of moisture (10.8-14.04\%) and ash (2.22-3.38\%) were reported. A good safety profile was obtained with low nitrite and nitrate levels, with undetectable heavy metals and no significant growth of pathogenic microorganism except mould. Epidermal growth factor was detected but below the quantification level with the chicken EGF ELISA kit. The microculture tetrazolium (MTT) assay was performed for growth stimulation assessment comparing human EGF and EBN. There was no significant cell growth observed in cancer cells after EBN treatment. In conclusion, EBN Malaysia has a good nutritional profile, free of heavy metals, and an acceptable level of nitrate, nitrite, and microorganism profile except for mould contents. Furthermore, the in vitro study indicated that EBN was not associated with cancer cell growth.

\section{Introduction}

Edible Bird's Nest (EBN) is solidified saliva of Aerodramus fuciphagus. EBN has been used as the main ingredient in Traditional Chinese Medicine and cuisine as early as the Tang (618-907 AD) and Sung (960-1279 AD) dynasties [1]. EBN has been regarded as a luxurious local delicacy which contains high nutritional values and various medicinal properties [2]. High nutritional and medicinal values of EBN and the danger and difficulty of the nest collection process have made EBN as one of the world's most valuable animal food products consumed by mankind with an average selling price of \$ 2500 per kilogram.

A few studies carried out looking into the proximate analyses of EBN in Malaysia [3, 4] and from neighbouring countries such as Indonesia [5] and Thailand [6] had concluded that EBN is a good source of protein, carbohydrate, and some trace elements. However, previous studies had reported a wide range of protein and carbohydrate contents from Malaysia EBN despite using the same method. Moreover, the analyses previously performed were not representative of all regions in Malaysia [3, 4, 7]. Despite being acclaimed as a nutritious food, there are many safety issues arising from Malaysia EBN in recent years; namely, high nitrate and nitrite contents [8,9], EBN adulteration [5], presence of heavy metal $[4,10]$, pathological microorganism, and fungal infection [11]. The contaminants in EBN may be potentially harmful to the consumers. High intake of nitrate and nitrite were reported to be associated with an increased 
risk of stomach cancer [12]. The incident of Malaysia EBN was banned from exportation raised the public's concern about the high level of nitrite in EBN [8]. Meanwhile, microorganisms and fungal infections could lead to systemic or gastrointestinal infections [13]. Pigskin, karaya gum, Tremella fungus, and red seaweed are the common materials used in EBN adulteration for profit-making scams. It has proven to reduce EBN's nutritional value [5]. Moreover, Malaysia experiences severe haze pollution every year due to open burning. From the author's observation, the EBN collected during high Air Pollution Index (API) appeared to be dirtier and darker in colour. Hence, this study also wants to determine the nutritional and safety profile of the hazeaffected EBN. This will be the first pilot study looking into the haze-affected EBN. In a nutshell, this paper aims to establish the proximate analysis and safety profile in terms of heavy metal, microorganism, and also nitrate and nitrite contents of EBN from different regions in Malaysia.

Some of the impressive medicinal properties of EBN identified include potent anti-inflammatory activity by suppressing the production of tumour necrosis factor alpha $(\mathrm{TNF}-\alpha)$ [14], inhibition of influenza virus infection [15], cytoprotective properties from cyclophosphamide [16], neuroprotective effect [17], EGF like peptide which promotes cell proliferation [18], and estradiol hormones [19] which may be beneficial in women health by improving menstrual dysfunctions. EGF was first found to be present in EBN back in 1987. EGF in EBN was detected by using radioreceptor assay [18] and Western blot [20]. Human EGF is known to have the ability to stimulate cell growth and proliferation. It acts as a mitogenic factor that plays a growth-stimulating role in various epidermal and epithelial tissues. Hence, EBN is also deemed to have rejuvenating and antiaging properties. However, the receptor for EGF (EGFR) has been found highly expressed in various solid tumors. The dysregulation of EGF is also associated with the growth and progression of many cancers [21]. In addition, a previous paper had shown that EBN may stimulate colon cancer cell (Caco-2) growth in vitro [14]. Hence, this paper intends to quantify the amount of EGF in EBN and also looking into the possibility of proliferative effect of human cancer cells due to EBN consumption.

\section{Materials and Methodology}

2.1. Sample Collection and Preparation. Seven raw cleaned EBN samples were sourced from 6 different regions in Malaysia (Figure 1): A from Alor Setar, Kedah (northern region), B from Sibu, Sarawak (east region), C from Rompin, Pahang (east coast region), D from Kuala Selangor (west coast region), E from Johor Bahru (southern region), $\mathrm{F}$ from Jerantut, Pahang (central region), and G from Port Klang (west coast region). A total of $200 \mathrm{~g}$ bird nests were collected from a single bird farm in each region. The EBN was also collected specifically during the heavy haze period in March 2014 with an API of 100-200 for a month from Port Klang and compared with EBN collected from healthy API $<100$ level area in Jerantut. The EBN sample collected from Port Klang grossly appeared to be in darker colour likely due to heavy haze comparing the EBN sample collected from Jerantut during the same period of time (Figure 2). The EBN cleaning process was performed by the respective factories from different regions in Malaysia. Raw EBN was first soaked in clean water for 1 hour until the soft and glutinous material became partially loosened. The remaining feathers and dirt were removed manually using tweezers with the aid of magnifying glasses. The cleaned EBN was subsequently fan-dried at room temperature and shaped using a mould. All 7 samples of EBN were subsequently given a specific code and were blinded throughout the experiments: EBN 01 was C, EBN 02 was B, EBN 03 was E, EBN 04 was G, EBN 05 was $\mathrm{A}, \mathrm{EBN} 06$ was D, and EBN 07 was $\mathrm{F}$.

2.2. Cell Lines. MCF-7 are human breast adenocarcinoma cells, A549 are human alveolar adenocarcinoma cells, Caco2 are human epithelial colorectal adenocarcinoma cells, and HCT116 are human colorectal carcinoma cells which were purchased from American Tissue Culture Collection (ATCC) (Virginia, USA).

2.3. Chemical/Reagents. The pepsin and pancreatin enzymes were purchased from Nacalai Tesque Inc. (Kyoto, Japan). The chicken EGF ELISA kit was purchased from Cusabio Technology LLC (Houston, USA). Sodium hydrogen carbonate, sodium bicarbonate, hydrochloric acid, sodium hydroxide, foetal bovine serum (FBS), and biological-grade dimethylsulfoxide (DMSO) were purchased from Sigma-Aldrich (St. Louis, USA). Roswell Park Memorial Institute (RPMI) 1640 medium with L-glutamine, 2.5\% trypsin (10x), and 10,000 U/ $\mathrm{mL}$ penicillin $-10 \mathrm{mg} / \mathrm{mL}$ streptomycin were purchased from GIBCO (New York, USA). Phosphate-buffered saline (PBS) was from Life Technologies (Maryland, USA) and 3-(4,5-dimethylthiazol-2-yl)-2,5-diphenyltetrazolium bromide (MTT) was from Molecular Probes (Oregon, USA). Human EGF (hEGF) was purchased from Pepro Tech Inc (New Jersey, USA).

2.4. Tissue Culture Materials. The tissue culture materials consisted of $25 \mathrm{~cm}^{2}$ and $75 \mathrm{~cm}^{2}$ plastic tissue culture flasks, 96-well flat-bottom tissue culture plates, $10 \mathrm{~mL}$ serological pipettes, and $15 \mathrm{~mL}$ plastic centrifuge tubes.

2.5. Proximate and Safety Profile Analysis. The analysis of total dry matter content of EBN was carried out by a food lab CHEMSIL (AIR \& WATER) which was accredited under the Malaysia Accredited Laboratory Scheme ISO/IEC 17025. The official methods of the Association of Official Analytical Chemistry (AOAC) were employed to determine protein, carbohydrate, moisture, ash, and fat contents of the raw, cleaned EBN [22]. The crude protein content was determined by the Kjeldahl's method, using 6.25 as a conversion factor (AOAC Method 2001.11). Carbohydrate, free fat, moisture, and ash content were determined by AOAC 986.25E, Malaysia standard: 954 PART 5:2000, AOAC 950.46, and AOAC 923.03, respectively. The moisture content was determined by drying and heating the EBN at 


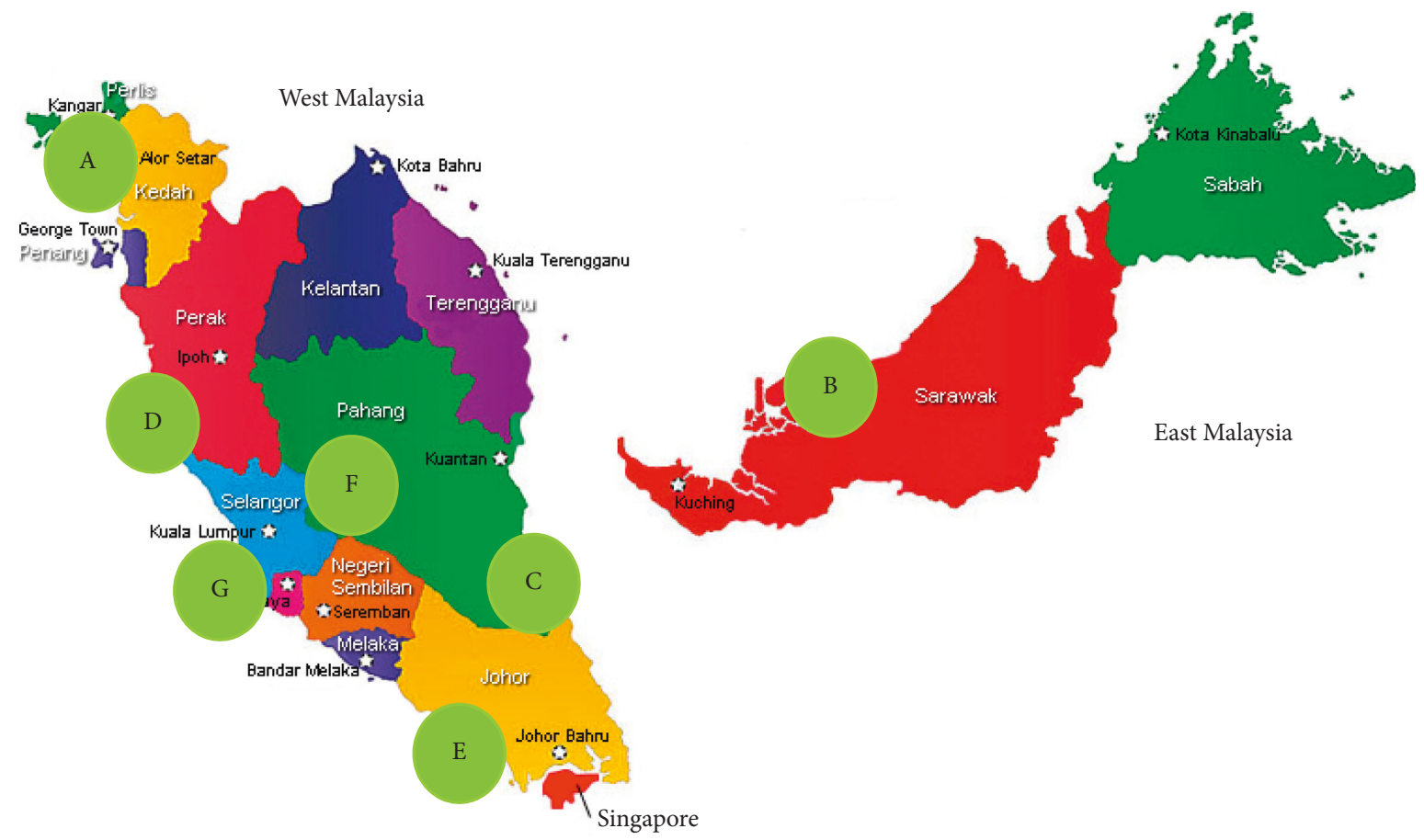

EBN collection region

FIGURE 1: Seven raw, cleaned EBNs collected from different regions in Malaysia.

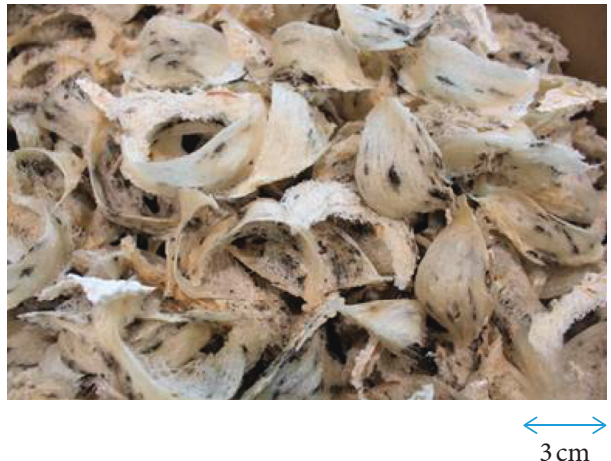

(a)

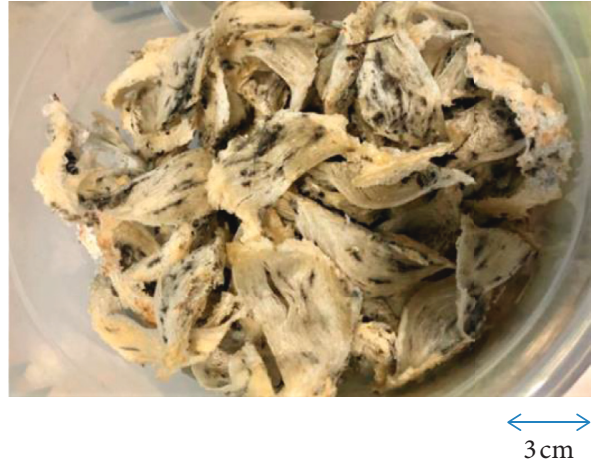

(b)

FIgURE 2: The physical appearance of raw, cleaned EBNs collected from Jerantut (F) with API $<100$ (a) and Port Klang (G) during the haze period with unhealthy API 100-200 (b).

$105^{\circ} \mathrm{C}$ until a constant weight was obtained. The ash content was obtained by drying the EBN in a furnace at $550^{\circ} \mathrm{C}$ for 18 hours. The carbohydrate content was determined by the difference method (100\% dry matter subtracting the percent of crude protein, ash, moisture, and fat). The method to determine nitrate and nitrite contents of EBN was based on the Malaysia Standard MS 2509:2012. A $20 \mu \mathrm{L}$ of EBN extract was injected into an ion chromatograph for analysis. Heavy metal content in EBN was analyzed using the In-House Method based on AOAC 999.11. EBN was dried and ashed at $450^{\circ} \mathrm{C}$. $6 \mathrm{M}$ HCL was added, and the solution was evaporated to dryness. The residue was dissolved in $0.1 \mathrm{M} \mathrm{HNO}_{3}$, and flame and graphite procedures were carried out to determine the heavy metal level. The microbiological compound was determined by the Australian Standard for Escherichia coli, Samonella spp., Coliform, and total plate count [23-25]. On the other hand, the official AOAC method was performed for Staphylococcus aureus content and Bacteriological Analytical Manual of Food and Drug Authority for mould and yeast content [26].

2.6. EBN Preparation. EBN extract was prepared as described by Goh et al. with modifications [27]. Briefly, about $1 \mathrm{~g}$ EBN was crushed to powder using pestle and mortar. The powdered EBN sample measured about $0.5-1 \mathrm{~mm}$ in size 
and was subsequently mixed with $100 \mathrm{~mL}$ of ultrapure water in a conical flask and mixed thoroughly. The mixture in the conical flask was then simmered in a pot (doubled boiled method) at $100^{\circ} \mathrm{C}$ in a water bath for 1 hour following the Chinese technique of cooking to preserve the taste. The extract was frozen in $-80^{\circ} \mathrm{C}$ and subsequently freeze-dried into dry powder in a freeze dryer. It was stored at $-20^{\circ} \mathrm{C}$ until required for further use.

2.7. Extract Digestion. The EBN extract subsequently underwent the pepsin-pancreatin enzyme digestive process [28]. Firstly, the $\mathrm{pH}$ of the EBN extract was adjusted to 2.0 with 1.0 M HCL. Pepsin was then added, and the mixture was incubated at $37^{\circ} \mathrm{C}$ for 2 hours in a shaking water bath. After that, the $\mathrm{pH}$ value was adjusted to 5.3 with $0.9 \mathrm{M} \cdot \mathrm{NaHCO}_{3}$ solution and later to 7.5 with $1.0 \mathrm{M} \cdot \mathrm{NaOH}$. Subsequently, pancreatin was added to the mixture and was reincubated at $37^{\circ} \mathrm{C}$ for 2 hours. The reaction was terminated by keeping in the mixture in a test tube boiling for 10 minutes. The mixtures were cooled at room temperature, filtered, freeze-dried, and finally stored at $-20^{\circ} \mathrm{C}$ until later use. The whole EBN extract preparation was performed mimicking the human digestive tract [19].

2.8. Preparation of Test Compound. Freeze-dry EBN was partly dissolved in ultrapure water and filtered with a syringe filter to make a stock solution with a concentration of $100 \mu \mathrm{g} / \mathrm{mL}$. It was stored at $4^{\circ} \mathrm{C}$ until required for further use.

2.9. Sample Concentration. Four $\mathrm{mL}$ of digested EBN extract was centrifuged with Amicon ultracentrifugal filters at $3000 \mathrm{rpm}$ for 120 minutes with 3 minutes rest in between. The final volume for all EBN samples was $0.4 \mathrm{~mL}$ after concentration. The EBN sample was 10 times concentrated postprocedure.

2.10. ELISA Method. EGF assays were measured by using the 96-well plates (Cusaibo). $100 \mu \mathrm{L}$ of standard and EBN was added per well and incubated for 2 hours at $37^{\circ} \mathrm{C}$. Ultrapure water served as the negative control. The liquid was removed. Then, $100 \mu \mathrm{L}$ of Biotin-antibody was added to each well and incubated for 1 hour at $37^{\circ} \mathrm{C}$. Each well was aspirated and washed with $200 \mu \mathrm{L}$ of buffer for a total of three times. Followed by the addition of $100 \mu \mathrm{L}$ of horseradish peroxidase-avidin into each well, the plate was incubated for 1 hour at $37^{\circ} \mathrm{C}$. The process of aspiration and washing was done for a total of 5 times. Then, $90 \mu \mathrm{L}$ of tetramethylbenzidine substrate was added to each well and incubated for $15-30$ minutes at $37^{\circ} \mathrm{C} .50 \mu \mathrm{L}$ of stop solution was subsequently added and thoroughly mixed. The absorbance at $450 \mathrm{~nm}$ and $570 \mathrm{~nm}$ were read using a Versamax microplate reader (Molecular Devices LLC, California, USA).

2.11. General Cell Culture Procedures. The cancer cells were cultured in a flask containing $5 \mathrm{~mL}$ of fresh medium at the subcultivation ratio of $1: 4$. The cultures were subsequently incubated at $37^{\circ} \mathrm{C}\left(5 \% \mathrm{CO}_{2}\right.$ and $95 \%$ air $)$ until at least $80 \%$ of the flask was fully occupied, and then the subculture process was repeated. The cells were washed with phosphate-buffered saline (PBS), and $1 \mathrm{~mL}$ of trypsin-Ethylenediaminetetraacetic acid (EDTA) was added. After 5-10 minutes, the monolayer cells detached. $3 \mathrm{~mL}$ of complete growth medium was added to inactivate trypsin. Repeated gentle pipetting was applied to split the clumped cell apart. $0.5-1 \times 10^{6}$ were subcultured into a new flask containing $10 \mathrm{~mL}$ of fresh medium and incubated at $37^{\circ} \mathrm{C}\left(5 \% \mathrm{CO}_{2}\right.$ and 95\% air).

2.12. Plating. Once the cancer cells had subconfluency, they were detached by using trypsin-EDTA. The detached cells were then suspended in $6 \mathrm{~mL}$ of serum-free culture medium with repeated gentle pipetting technique. The cell concentration was determined with a haemocytometer. Two thousand cells in $0.18 \mathrm{~mL}$ culture medium were dispensed into each well of 96-well flat-bottom tissue culture plates.

The cell concentration was adjusted using the culture medium according to the following formula as follows:

$$
M_{1} V_{1}=M_{2} V_{2} \text {, }
$$

where $M_{1}=$ initial cell concentration, $V_{1}=$ initial cell suspension volume, $M_{2}=$ final cell concentration, and $V_{2}=$ final cell suspension volume.

Using the multichannel pipette, $0.18 \mathrm{~mL}$ of cell suspension was dispensed into each well. The plate was incubated overnight at $37^{\circ} \mathrm{C}\left(5 \% \mathrm{CO}_{2}\right.$ and $95 \%$ air $)$ before treatment.

2.13. Microculture Tetrazolium (MTT) Assay. The Caco-2, MCF-7, HCT116, and A549 cancer cell lines were tested with physiological concentrations of hEGF at 0.0001, 0.001, 0.01, $0.1,1,10,100 \mathrm{ug} / \mathrm{mL}$ comparing with same concentration ranges of EBN 07 at $0.0001,0.001,0.01,0.1,1,10,100 \mu \mathrm{g} / \mathrm{mL}$. Two thousand cancer cells in $0.18 \mathrm{~mL}$ in serum-free medium were plated into each well of a 96-well plate and starved for 24 hours in the $\mathrm{CO}_{2}$ incubator. The cells in the culture plate were then directly visualized by using a microscope to ensure the cell had all attached to the wall of the well. The cells were then treated with $20 \mu \mathrm{L}$ of different concentrations of EBN and EGF as mentioned above. The cancer cells treated with $20 \mu \mathrm{L}$ of FBS $10 \%$ served as the positive control, while the cancer cells treated with $20 \mu \mathrm{L}$ of distilled water served as the negative control. The cells were continued to incubate for 24 , 48 , and 72 hours.

2.14. MTT Cell Viability Assay. After treatment, $50 \mu \mathrm{L}$ of MTT stock solution $(2 \mathrm{mg} / \mathrm{mL})$ was added into each well. Then the culture was incubated for another 4 hours. The mixture of culture medium and MTT solution was aspirated, and the formazan crystals formed were solubilized with $100 \mu \mathrm{L}$ of analytical-grade DMSO. The absorbance of the formazan solution at a wavelength of $450 \mathrm{~nm}$ was measured by using the Versamax microplate reader. The cell viability at 
time-zero was evaluated at 24,48 , and 72 hours postseeding, of which absorbance was measured.

The percent of cell growth was calculated by using the following formula:

$$
\frac{(\mathrm{AT})}{(\mathrm{AC})} \times 100
$$

where $\mathrm{AT}=$ absorbance of treatment groups at 24, 48, and 72 hours posttreatment and $\mathrm{AC}=$ absorbance of the vehicle control group at 24, 48, and 72 hours after treatment.

The values of the cell viability were presented as the mean triplicate $(n=3) \pm$ standard deviation (SD).

2.15. Statistical Analysis. The data are represented as mean \pm standard deviation. Statistical Package for Social Sciences (SPSS) version 22 software by IBM (New York, USA) was performed to determine statistically significant differences. One-way and two-way analyses of variance (ANOVA) were used in the statistical analysis, in which Bonferroni post hoc test with a confidence interval adjustment of least significant difference was applied. Statistically significant differences were determined by $p<0.05$.

\section{Results and Discussions}

3.1. Proximate Analysis. In this study, the order of EBN composition (from highest to lowest) is protein, carbohydrate, moisture, ash, and lipid (Table 1). The protein content ranges from 53\%-56\%, which were lesser than EBN collected in Thailand [6] and a local study [3] (60.9\%-66.9\% and $56 \%-61.5 \%$, respectively). In contrast, our protein content range was higher than those collected from Penang and Indonesia which was 24\%-49\% [7] and in Batu Pahat, Johor which was $35.8 \%$ [4] by using the same method for protein analysis. A previous study reported the overall crude protein content could reduce by $1.1-6.2 \%$ with the incorporation of adulterant products [5]. Our result had shown good consistency with no significant differences in terms of protein content in EBN from different regions in Malaysia. This can be possibly explained by the fact that the saliva was produced by the same species of swiftlet even though they have different habitat environments. The total carbohydrate content in this study ranged from $27.97 \%-31.68 \%$. This finding was close to a study on the nutritional composition of the farmed EBN in Thailand with the carbohydrate content ranging from $25.4 \%-31.4 \%$ [6]. The crude fat levels in all samples were consistent at $0.1 \%$, which was the lowest in comparison with previous papers $[5-7,29]$. The amount of fat content present in EBN was too small in amount, and its function is still unclear. The moisture content of all collected EBN samples was within the tolerance level $(<15 \%)$, ranging from $10.80 \%$ to $14.04 \%$. The moisture level was likely affected by the cleaning and drying process of EBN which varies from one factory to another factory. The EBN storage method may also affect the moisture level. Lastly, the ash content ranged from $2.22-3.38 \%$, which was relatively low compared with other studies which were ranging from $2.1 \%-7.3 \%$ and $2.75 \%-7.5 \%$, respectively $[5,7,29]$. The higher level of ash may be indicating the cleaning process may not be done thoroughly. Even though the EBNs were collected from 6 different regions in Malaysia, but it was only collected from a single bird farm due to financial constraints. Hence, the result may not be representative of the whole regions in this study.

3.2. Safety Profile: Nitrate and Nitrite. There were significant differences in the nitrite level of EBN collected from different regions in Malaysia (Table 1). The highest nitrate and nitrite amount were found in $\mathrm{EBN}$ from region $\mathrm{C}$, but the readings were still within the tolerance level. The differences were likely attributed to the different bird farm environments such as humidity, $\mathrm{pH}$ and climate, contamination during harvesting, or the cleaning process of the collected EBN. There was no previous study done in comparison with nitrite and nitrate contents of the farmed EBN from different regions. Most studies were comparing farmed EBN with wild EBN. Paydar et al. reported cave EBN contained 5-fold higher nitrite content and 297-fold higher nitrate content than those in the farmed EBN [8], while another recent study found that the cave EBN contained 148-fold higher amount of nitrite and 367-fold higher amount of nitrate than the farmed EBN [9]. The finding was explained by the differences between the cave and swiftlet house environment, as the swiftlet soil and guano were constantly removed from the swiftlet house. Good ventilation in the birdhouse also helps to reduce bacterial anaerobic fermentation process. Traditionally, the red EBN also known as premium swiftlet's blood EBN had a very high market value compared with the white nest due to limited supply and was believed to have higher medicinal and nutritional value [8]. A few recent studies had shown that the redness of EBN can be attributed to nitrate and nitrite contamination in $\operatorname{EBN}[8,9,30]$. Nitrite, a nitrate's metabolite, has been commonly used as food additive or preservative. However, it is considered hazardous if the amount exceeded the daily allowance. Nitrate and nitrite itself are not carcinogenic, but nitrite may react with some dietary amine compounds to form carcinogenic nitrosamines which can cause stomach cancer [12]. Farmed EBN in Malaysia in this study appeared whitish in colour (Figure 2). Hence, it was not surprising that both the nitrate and nitrite level were not exceeding the tolerance level.

3.3. Safety Profile: Heavy Metal. Malaysia EBN from the regions studied was free from heavy metal (Table 1). The findings were similar to a local study done by Lee et al. who reported there was no detectable cadmium and mercury. But, there was presence of trace amounts of arsenic $(0.0237 \mathrm{mg} / \mathrm{kg})$ and lead $(0.0203 \mathrm{mg} / \mathrm{kg})$ [4]. On the other hand, another local study reported that 1 out of the 10 tested EBN samples had a high level of mercury in a raw, uncleaned EBN sample from Kluang [10]. Heavy metal contamination in EBN could be from within the swiftlet house farms such as rusty iron bars, lead-based paints, and mercury-contaminated water supply or during the processing or manufacturing processes of EBN. The chemicals and 
TABle 1: Proximate composition, safety profile, and microorganism profile of the different samples of EBN collected from different regions in Malaysia (A from Alor Setar, Kedah; B from Sibu, Sarawak; C from Rompin, Pahang; D from Kuala Selangor; E from Johor Bahru; F from Jerantut, Pahang; and G from Port Klang, Selangor).

\begin{tabular}{|c|c|c|c|c|c|c|c|c|}
\hline \multirow{2}{*}{ Parameters } & \multicolumn{7}{|c|}{ Regions } & \multirow{2}{*}{ Tolerance level } \\
\hline & $\mathrm{A}$ & B & $\mathrm{C}$ & $\mathrm{D}$ & $\mathrm{E}$ & $\mathrm{F}^{*}$ & $\mathrm{G}^{\mathfrak{E}}$ & \\
\hline \multicolumn{9}{|l|}{ Proximate analysis } \\
\hline Protein & $54.3 \pm 1.9^{\mathrm{a}}$ & $53.9 \pm 1.9^{\mathrm{a}}$ & $53.0 \pm 0.7^{\mathrm{a}}$ & $53.7 \pm 1.1^{\mathrm{a}}$ & $54.4 \pm 3.8^{\mathrm{a}}$ & $55.5 \pm 2.5^{\mathrm{a}}$ & $56.4 \pm 2.8^{\mathrm{a}}$ & NA \\
\hline Carbohydrate & $29.7 \pm 4.8^{\mathrm{b}}$ & $30.5 \pm 5.5^{\mathrm{b}}$ & $28.0 \pm 7.0^{\mathrm{b}}$ & $31.7 \pm 3.5^{\mathrm{b}}$ & $28.6 \pm 4.6^{\mathrm{b}}$ & $28.6 \pm 6.0^{\mathrm{b}}$ & $28.8 \pm 6.2^{\mathrm{b}}$ & NA \\
\hline Moisture & $10.8 \pm 0.8^{\mathrm{c}}$ & $12.4 \pm 1.4^{\mathrm{c}}$ & $12.3 \pm 1.2^{\mathrm{c}}$ & $13.1 \pm 0.3^{c}$ & $14.0 \pm 0.5^{\mathrm{c}}$ & $12.1 \pm 1.6^{\mathrm{c}}$ & $12.1 \pm 1.2^{\mathrm{c}}$ & $<15 \%$ \\
\hline Ash & $2.8 \pm 0.2^{\mathrm{d}}$ & $2.7 \pm 0.2^{\mathrm{d}}$ & $3.4 \pm 0.7^{\mathrm{a}}$ & $2.7 \pm 0.1^{\mathrm{d}}$ & $2.9 \pm 0.3^{\mathrm{d}}$ & $2.8 \pm 0.1^{\mathrm{d}}$ & $2.2 \pm 0.1^{\mathrm{a}}$ & NA \\
\hline Crude fat & 0.1 & 0.1 & 0.1 & 0.1 & 0.1 & 0.1 & 0.1 & NA \\
\hline \multicolumn{9}{|l|}{ Safety profile } \\
\hline Nitrate & $24.9 \pm 0.5^{\mathrm{a}}$ & $39.4 \pm 1.0^{\mathrm{b}}$ & $52.6 \pm 0.9^{c}$ & $47.0 \pm 0.6^{\mathrm{d}}$ & $41.5 \pm 0.5^{\mathrm{e}}$ & $31.1 \pm 0.5^{\mathrm{f}}$ & $35.9 \pm 0.1^{\mathrm{g}}$ & NA \\
\hline Nitrite & $10.1 \pm 0.4^{\mathrm{a}}$ & $10.4 \pm 0.2^{\mathrm{a}}$ & $18.4 \pm 0.4^{\mathrm{b}}$ & $15.8 \pm 0.1^{c}$ & $11.0 \pm 0.2^{\mathrm{d}}$ & $10.3 \pm 0.1^{\mathrm{a}}$ & $11.4 \pm 0.2^{\mathrm{e}}$ & $<30$ \\
\hline \multicolumn{9}{|l|}{ Heavy metal } \\
\hline Arsenic & $<0.01$ & $<0.01$ & $<0.01$ & $<0.01$ & $<0.01$ & $<0.01$ & $<0.01$ & $<2$ \\
\hline Mercury & $<0.01$ & $<0.01$ & $<0.01$ & $<0.01$ & $<0.01$ & $<0.01$ & $<0.01$ & $<1$ \\
\hline Lead & $<0.02$ & $<0.02$ & $<0.02$ & $<0.02$ & $<0.02$ & $<0.02$ & $<0.02$ & $<0.05$ \\
\hline Cadmium & $<0.01$ & $<0.01$ & $<0.01$ & $<0.01$ & $<0.01$ & $<0.01$ & $<0.01$ & $<1$ \\
\hline & & & & & & & & $<100$ \\
\hline \multicolumn{9}{|l|}{ Microorganism } \\
\hline E. Coli & ND & ND & ND & ND & ND & $\mathrm{ND}$ & ND & NA \\
\hline S. Aureus & ND & ND & ND & ND & ND & $\mathrm{ND}$ & ND & $<100$ \\
\hline Salmonella & ND & ND & ND & ND & ND & ND & ND & $\mathrm{D} / \mathrm{ND}$ \\
\hline Coliform & 43 & 20 & ND & ND & ND & ND & 23 & $<1100$ \\
\hline Mould & 40 & 20 & 140 & 40 & $<10$ & 20 & 30 & $<10$ \\
\hline Yeast & 10 & $<10$ & $<10$ & $<10$ & $<10$ & $<10$ & $<10$ & $<10$ \\
\hline Total plate count & $12 \times 10^{5}$ & $9.5 \times 10^{5}$ & $5 \times 10^{5}$ & $2.3 \times 10^{5}$ & $3.2 \times 10^{5}$ & $1.8 \times 10^{5}$ & $16 \times 10^{5}$ & $<25 \times 10^{5}$ \\
\hline
\end{tabular}

Mean $\pm \mathrm{SD}(n=3)$. ND = not detected; $\mathrm{D}=$ detected; NA = not applicable. ${ }^{*} \mathrm{EBN}$ collected during API $100-200$ (polluted air); ${ }^{\mathfrak{E}} \mathrm{EBN}$ collect during API $<100$. Proximate analysis results were expressed in $\mathrm{g} / 100 \mathrm{~g}$ of EBN; safety profile results were expressed in $\mathrm{mg} / \mathrm{kg}$ of EBN; microorganism profile results were expressed in MPN/g or CFU/g of EBN on the dry basis. ${ }^{a-g}$ mean in category row with the same letter are not significantly different $(p>0.05)$.

materials used could also be a source of heavy metals [10]. Heavy metals cannot be biodegraded. They were known to have long-term cumulative effects in humans, causing various diseases and disorders even at relatively low concentrations [31]. Therefore, it is important to study the levels of these elements in EBN to ensure the safety profile.

3.4. Safety Profile: Microbiology Profile. There was very limited literature describing the microbiology profile of EBN. Escherichia coli, Coliform, Staphylococcus aureus, and Salmonella spp. which may cause serious gastrointestinal infections to humans [13] after consumption were absent in all EBN samples (Table 1). The safety profile in terms of microorganism was further supported by the low total plate count in EBN from all regions. Mould is a type of fungus that is multicellular and grows in hyphae, while yeast is a type of single-cell fungus. Both organisms belonged to the Fungi kingdom. All EBN samples had a high level of mould except the EBN from region A. Meanwhile, yeast content for all EBN samples was within the tolerance level. A study done found that the amount of yeast and mould had exceeded the limit set by SIRIM for all EBN [11]. The common fungi that isolated were Aspergillus sp., Candida sp., Cladosporium sp., Neurospora sp., and Penicillium sp. In the same study, there was no significant difference $(p>0.05)$ in the reduction of the number of fungi even after boiling the EBN. The high level of fungus growth may be due to the environment of the bird farm which has a lower temperature, with high-level humidity or moisture. The fungus is usually benign and rarely causing serious infection in an immunocompetent host. However, EBN has been recognized as prestigious food with multiple medicinal properties. Hence, many consumers who have medical illness or in the immunocompromised state, for example, malignancy, on long-term steroid, diabetes mellitus, or organ transplant recipients may develop severe opportunistic fungal infections after consuming EBN. Further studies are needed to determine the effect of fungus growth in EBN on humans. Besides that, an effective method to remove fungal contaminations in EBN needs to be developed for safe consumption. With the finding of high level of mould, this issue should be highlighted, and prompt action is necessary. The presence of these microorganisms may jeopardize the quality of EBN and pose health risks to consumers. Hence, the standards of EBN should be monitored regularly to ensure the quality of EBN and consumer safety.

3.5. Comparing EBN Collected during the Haze Period. In this study, there are differences in terms of physical appearance as the EBN collected from Port Klang during API 100-200 appeared to be darker and dirtier (Figure 2). There was no significant difference in protein, carbohydrate, ash, crude fat, moisture, and nitrate and nitrite contents (Table 1). EBN from both areas has similar heavy metal and microbiology 
TABLE 2: Chicken EGF ELISA quantification results of seven crude and digested EBN samples from six different regions in Malaysia and post-ultracentrifugal filter of the digested EBN from three selected regions (EBN 01, 02, and 07).

\begin{tabular}{lccc}
\hline & $\begin{array}{c}\text { Crude sample concentration } \\
(\mathrm{pg} / \mathrm{mL})\end{array}$ & $\begin{array}{c}\text { Digested sample concentration } \\
(\mathrm{pg} / \mathrm{mL})\end{array}$ & $\begin{array}{c}\text { Digested sample post-ultracentrifugal filter } \\
\text { concentration }(\mathrm{pg} / \mathrm{mL})\end{array}$ \\
\hline Negative & 0 & 0 & NA \\
control & 30.7 & 0 & 0 \\
EBN 01 & 74.5 & 0 & 0 \\
EBN 02 & 0 & 0 & NA \\
EBN 03 & 0 & 0 & NA \\
EBN 04 & 0 & 0 & NA \\
EBN 05 & 0 & 0 & NA \\
EBN 06 & 0 & 0 & 0 \\
EBN 07 & 0 & 0 & \\
\hline
\end{tabular}

Mean \pm SD $(n=3)$. NA: not applicable. EBN 01 from Rompin, Pahang; EBN 02 from Sibu, Sarawak; EBN 03 from Johor Bahru, Johor; EBN 04 from Port Klang, Selangor; EBN 05 from Alor setar, Kedah; EBN 06 from Kuala Selangor, Selangor; EBN 07 from Jerantut, Pahang. Results expressed in pg/mL of EGF. The detection range of chicken EGF ELISA kit: $125-8000 \mathrm{pg} / \mathrm{mL}$.

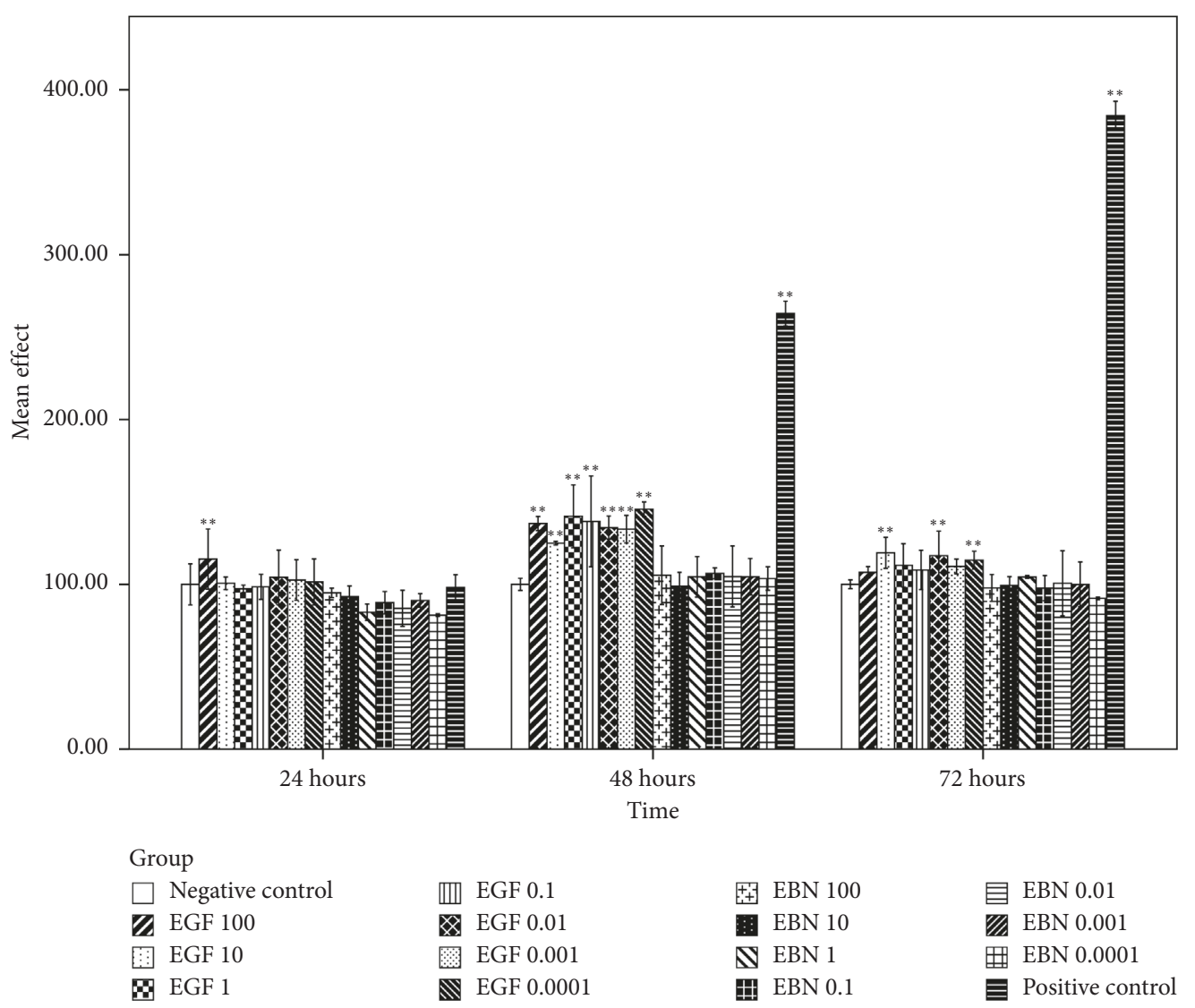

FIGURE 3: Caco-2 cell viability posttreatment with different concentrations of hEGF $(0.0001,0.001,0.01,0.1,1,10$, and $100 \mu \mathrm{g} / \mathrm{mL})$ and EBN $(0.0001,0.001,0.01,0.1,1,10$, and $100 \mu \mathrm{g} / \mathrm{mL})$ at 24,48 , and 72 hours by an assessment of cell viability using MTT assay. Cell viability is presented as mean $(n=3) \pm$ SD. Statistically significant differences were determined by two-way ANOVA with Bonferroni post hoc test, and a confidence interval adjustment of least significant difference was applied; $p<0.05\left(^{*}\right)$ and $p<0.01\left(^{* *}\right)$ compared with the negative control (ultrapure water). The positive control was treated with FBS.

profiles (Table 1). The same result was also observed when comparing with other EBN collected from other different regions without air pollution period which we had reported earlier. Therefore, there were no significant differences found in terms of nutritional profile, heavy metal, and microbiology profile of these haze-contaminated samples.
3.6. EGF Quantification. There was the presence of $30.7 \mathrm{pg} /$ $\mathrm{mL}$ and $74.5 \mathrm{pg} / \mathrm{mL}$ of EFG in crude EBN 01 and EBN 02, respectively (Table 2). However, both of the detected levels were below the quantification limit of the ELISA kits (125 pg/ $\mathrm{mL}-8000 \mathrm{pg} / \mathrm{mL}$ ). There was no detected EGF found in all digested EBNs and digested EBNs from three selected 


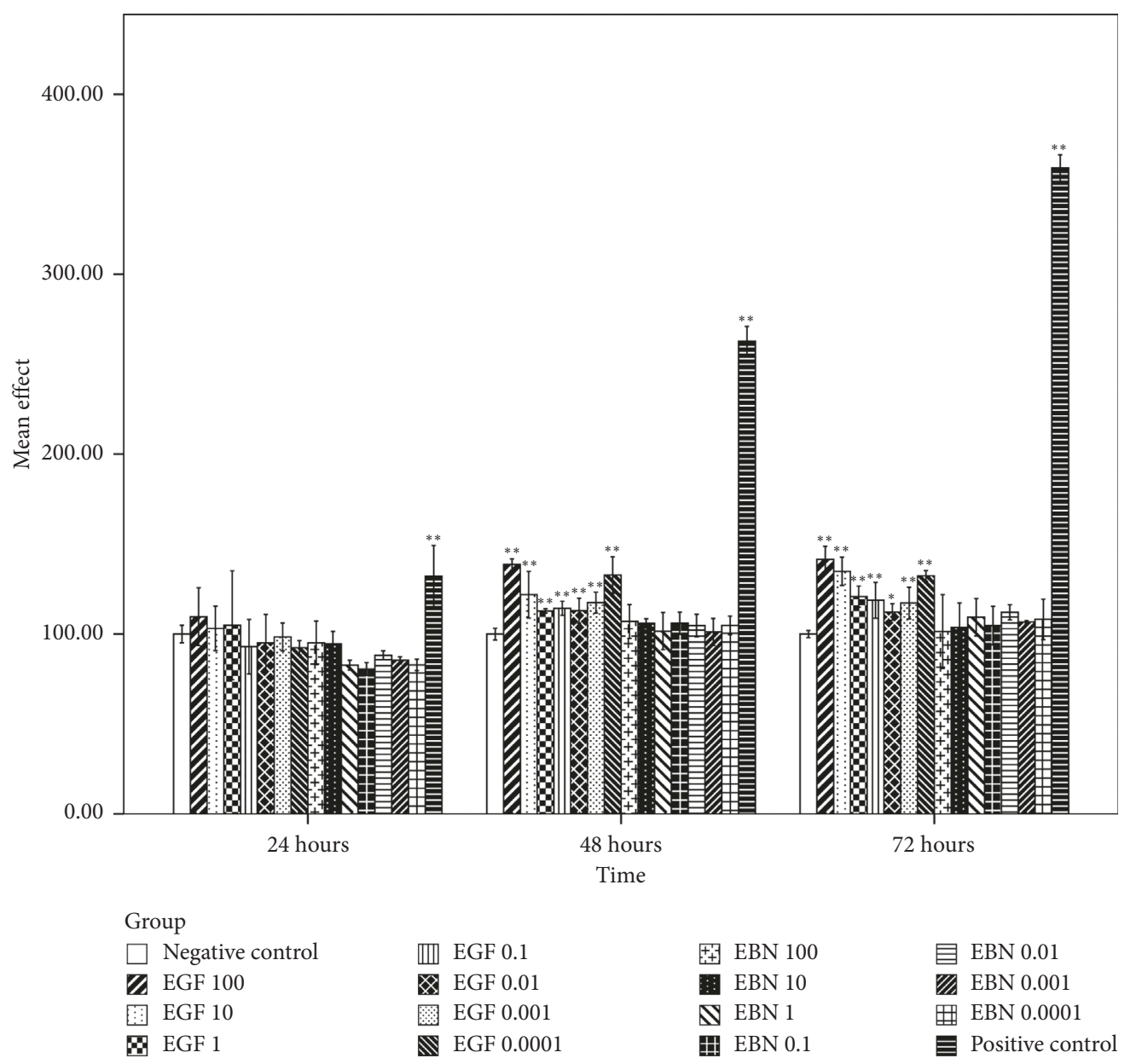

FIGURE 4: MCF-7 cell viability posttreatment with different concentrations of hEGF $(0.0001,0.001,0.01,0.1,1,10$, and $100 \mu \mathrm{g} / \mathrm{mL})$ and EBN $(0.0001,0.001,0.01,0.1,1,10$, and $100 \mu \mathrm{g} / \mathrm{mL})$ at 24,48 , and 72 hours by an assessment of cell viability using MTT assay. Cell viability is presented as mean $(n=3) \pm$ SD. Statistically significant differences were determined by two-way ANOVA with Bonferroni post hoc test, and a confidence interval adjustment of least significant difference was applied; $p<0.05\left(^{*}\right)$ and $p<0.01\left(^{* *}\right)$ compared with the negative control (ultrapure water). The positive control was treated with FBS.

regions (EBN 01, 02, and 07), despite the post 10 times concentration of the EBN (Table 2). The 3 selected samples went ahead with the ultracentrifugal filter process given the low level of EGF detected in crude EBN 01 and EBN 02 while EBN 07 was selected for cancer cell work. The result had shown the presence of EGF in EBN. However, we failed to quantify the amount of EGF in all EBN samples by using the ELISA quantification assay. A few factors were identified which affected the result. First of all, the protein may be denatured during the EBN cooking process. Subsequently, during the enzyme digestion process, EBN was undergoing artificial digestion pathway to mimic the human digestive tract which may further alter the protein nature. This may be explained by the ELISA result whereby there was a detection of EGF in crude EBN but not found in digested EBN. Secondly, freeze-dried EBN appeared to be fine pale powder, but it became thick gelatinous liquid again after adding a small amount of ultrapure water. Hence, it required a large amount of ultrapure water to partly dissolve the freeze-dried EBN leading to the possibility of overdiluted sample. Thirdly, freshly prepared EBN extract after the boiling process appeared to be like EBN soup which contained EBN aqueous form and insoluble jelly-like substance. Only the aqueous form of EBN was able to be taken up by the pipetting method. Thereby, we postulated that EGF may have bound tightly to the insoluble jelly-like substance leading to underestimation of EGF. Insufficient extraction was previously highlighted as one of the reasons for low detection of EGF content in EBN [18]. Furthermore, Yang et al. had identified that only one kind of EGF antibody can specifically bound to the EGF of EBN after trial of multiple types of EGF primary antibodies [20]. They had used an antiEGF primary antibody and human anti-rabbit immunoglobulin conjugate as a secondary antibody in the immunoblotting assay. Similar to our present study, the ELISA kits used contained rabbit derived polyclonal antibody for chicken EGF detection. However, no previous study had used this chicken EGF ELISA kits in EGF detection for EBN. Therefore in future studies, we suggest the use of alternative quantification methods such as Western blot or radioreceptor assay as the previous study had proven the presence of EGF in EBN even though in a very small amount $[18,20]$. 


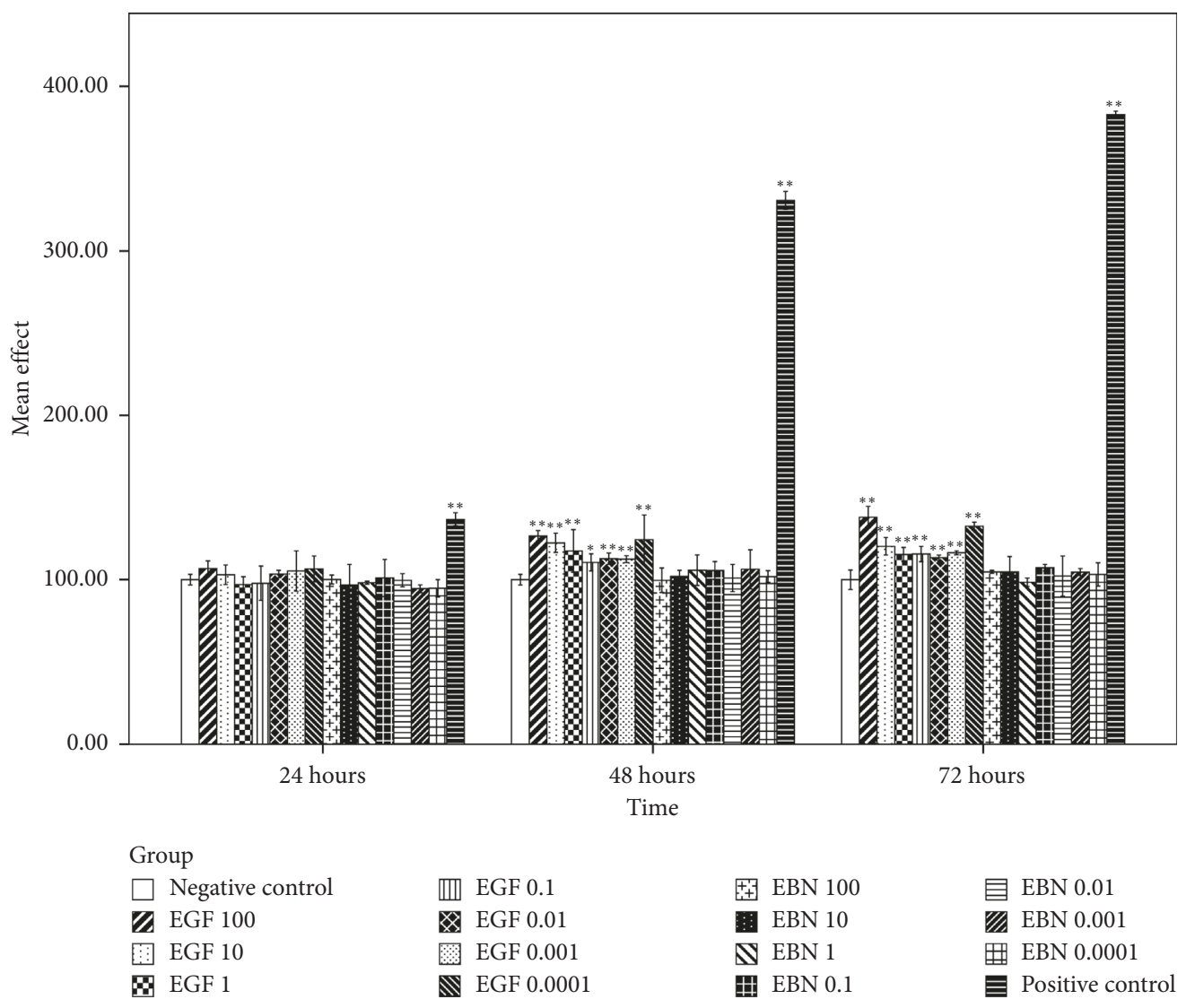

FIGURE 5: HCT 116 cell viability posttreatment with different concentrations of hEGF $(0.0001,0.001,0.01,0.1,1,10$, and $100 \mu \mathrm{g} / \mathrm{mL}) \mathrm{and}$ $\operatorname{EBN}(0.0001,0.001,0.01,0.1,1,10$, and $100 \mu \mathrm{g} / \mathrm{mL})$ at 24,48 , and 72 hours by an assessment of cell viability using MTT assay. Cell viability is presented as mean $(n=3) \pm$ SD. Statistically significant differences were determined by two-way ANOVA with Bonferroni post hoc test, and a confidence interval adjustment of least significant difference was applied; $p<0.05\left(^{*}\right)$ and $p<0.01\left(^{* *}\right)$ compared with the negative control (ultrapure water). The positive control was treated with FBS.

3.7. The Effect of EBN on the Growth of Cancer Cells. Based on Figure 3, the first significant post-hEGF treatmentinduced Caco-2 cell growth was observed at the highest concentration of hEGF, $100 \mu \mathrm{g} / \mathrm{mL}$, during the first 24 hours incubation period. It was followed by significant cell growth in all concentrations of hEGF treatment at 48 hours and with a concentration of $10,0.01$, and $0.0001 \mu \mathrm{g} / \mathrm{mL}$ at the incubation period of 72 hours. Cell growth with hEGF as high as $50 \%$ compared with negative control was observed. There was no significant Caco-2 cell growth after being treated with various concentrations of EBN at different intervals of time. MCF-7 and HCT116 cells that were treated with hEGF across all concentrations have significant cell growth at 48 and 72 hours. In contrast, no significant cell growth was seen after being treated with various concentrations of EBN (Figures 4 and 5). There was significant A549 cell growth after being treated with all ranges of hEGF concentrations at 24, 48, and 72 hours but no significant A549 cell growth after EBN treatment (Figure 6). A positive control cell was treated with FBS which showed marked significant cell growth. There was no significant cancer cell stimulation in all cancer cells after being treated with a wide range of concentrations from 100-0.0001 $\mu \mathrm{g} / \mathrm{mL}$ EBN extracts. However, most of the cancer cells grew well with the addition of hEGF indicating the presence of EGF does stimulate cancer cells growth. Since the discovery of EGF in EBN, there are very limited studies regarding the function and medicinal properties of the avian EGF. The human and avian EGFR was found to contain a complete coding sequence and was highly homologous, about $78 \%$ identical after the sequence of a cDNA clone in the primary structure of the chicken EGF receptor. However, the Basic Local Alignment Search Tool (BLAST) by the National Centre of Biotechnology Information was used to compare the human EGF amino acid sequence with the chicken EGF amino acid sequence and was found only at $36 \%$ identical. There was only 1 previous study showing significant dose-dependent growth of Caco-2 cells after being treated with EBN [14]. However, their postulation for the cancer cell growth factor was due to the presence of sialic acid in EBN instead of EGF. Besides that, the present of adulterants incorporated in EBN [5] may also be the reason for cancer cell stimulation. The percentage of cell proliferation comparing the control was as high as $215 \%$. In the contrary, there was no significant cancer cell growth despite being treated with a high or low concentration of EBN in this study. Our study findings were supported by Roh et al. reported that there were no observable effects on MCF-7 and Hep2B, human liver cancer [32]. The same study found that EBN has properties of promoting 34\% and 38\% increase in the cell proliferation rate of normal hADSCs and 


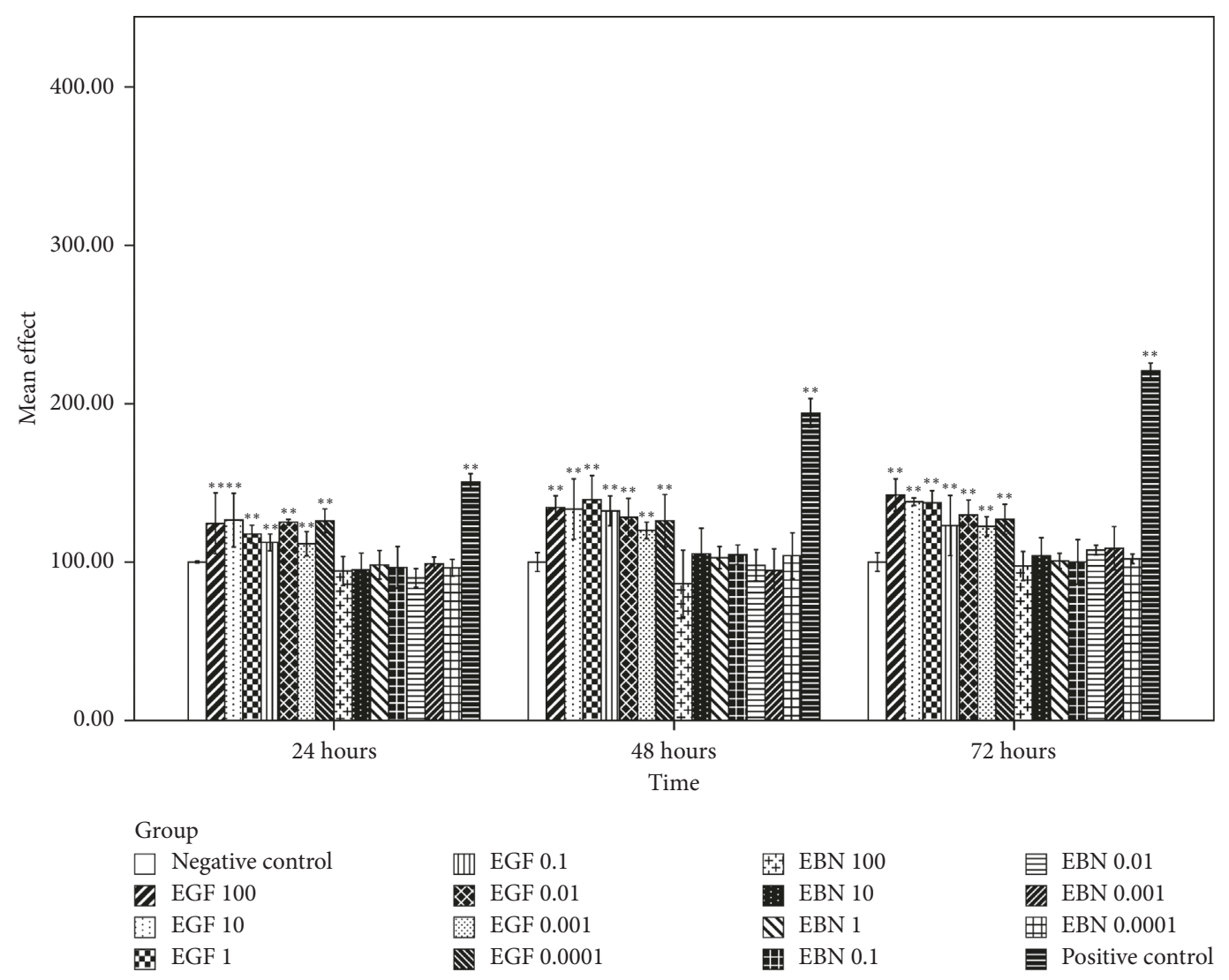

FIGURE 6: A549 cell viability posttreatment with different concentrations of hEGF $(0.0001,0.001,0.01,0.1,1,10$, and $100 \mu \mathrm{g} / \mathrm{mL})$ and EBN $(0.0001,0.001,0.01,0.1,1,10$, and $100 \mu \mathrm{g} / \mathrm{mL})$ at 24,48 , and 72 hours by an assessment of cell viability using MTT assay. Cell viability is presented as mean $(n=3) \pm$ SD. Statistically significant differences were determined by two-way ANOVA with Bonferroni post hoc test, and a confidence interval adjustment of least significant difference was applied; $p<0.05\left(^{*}\right)$ and $p<0.01\left(^{* *}\right)$ compared with the negative control (ultrapure water). The positive control was treated with FBS.

NHFs, respectively. Hence, they concluded that EBN was shown to affect normal human cells, but not the transformed cell line. In our study, the 4 selected types of cancer cells are according to the presence of EGF mutation in these particular cancer cells. In modern medicine, tyrosine kinase inhibitor as a cancer treatment for lung, colon, and breast carcinoma is well established. Hence, we postulated that the selected cancer cells may likely to have growth simulation by the presence of EGF content in EBN. There are a few factors that may affect the results. The protein or EGF extraction method may not be adequate to release all the relevant bioactive substances. Besides that, the content of EGF which present in EBN may be too minute to stimulate cancer cell growth, and the amount cannot compare with the same concentration of pure hEGF. There was only $36 \%$ identical amino acid sequence between hEGF and avian EGF which could explain why the EBN is unable to stimulate human cancer cells like hEGF. More studies are needed to research upon the proper extraction methods of pure EGF from EBN and quantification of EGF contents in order to carry out more precise experiments.

\section{Conclusion}

This study demonstrated that raw, cleaned EBN from different regions in Malaysia has good consistency in their proximate analysis, even during hazy periods. They contained high proteins and carbohydrates with low fat and ash content. Besides that, EBN is also safe to be consumed as no heavy metals were detected, with acceptable microbiology profile and the nitrite level within standards set by the government except the presence of mould above the tolerance level. EGF was detected in EBN, but the amount was below the quantification level via the ELISA method. Our results had demonstrated no significant cancer cell stimulation after being treated with different concentrations of EBN extract. Hence, EBN is safe to be consumed by the human in terms of carcinogenic risk.

\section{Data Availability}

The data used to support the findings of this study are available from the corresponding author upon request.

\section{Disclosure}

This paper has been previously presented as a poster in the International Conference on Drug Discovery and Translational Medicine 2018 in Putrajaya, Malaysia.

\section{Conflicts of Interest}

The authors declare that they have no conflicts of interest. 


\section{Acknowledgments}

This research was supported by a research grant from the Centre of Excellence (CoE) Swiflets, Faculty of Veterinary Medicine, Universiti Putra Malaysia (grant no. 647140010301-H5). The authors thank the Centre of Excellence (CoE) Swiflets, Faculty of Veterinary Medicine and Pharmacotherapeutics Laboratory, Universiti Putra Malaysia, for their support to this project. Also, the authors would like to take this opportunity to convey their gratitude to their research team members. The authors also thank Careena Shobana for facilitating in EBN preparation and her constant support, Teh Yuan Han for helping in the ELISA test, and also Michelle Tan Siying for guidance in terms of cell culture works.

\section{References}

[1] C. T. S. Lim, Make Millions from Swiftlet Farming: A Definitive Guide, Truewealth Sdn Bhd, Malaysia, 2006.

[2] M. Oda, S. Ohta, T. Suga, and T. Aoki, "Study on food components: the structure of N-linked asialo carbohydrate from the edible bird's nest built by Collocalia fuciphaga," Journal of Agricultural and Food Chemistry, vol. 46, no. 8, pp. 3047-3053, 1998.

[3] M. K. Norhayati, O. Azman, and N. W. M. Wan, "Preliminary study of the nutritional content of Malaysian edible bird's nest," Malaysian Journal of Nutrition, vol. 16, no. 3, pp. 389-396, 2010.

[4] T. H. Lee, A. W. Waseem, E. T. T. Tan, A. A. Nur, L. L. Yong, and A. A. Ramlan, "Investigations into the physicochemical, biochemical and antibacterial properties of edible bird's nest," Journal of Chemical and Pharmaceutical Research, vol. 7, no. 7, pp. 228-247, 2015.

[5] M. F. Marcone, "Characterization of the edible bird's nest the "Caviar of the East"," Food Research International, vol. 38, no. 10, pp. 1125-1134, 2005.

[6] W. Saengkrajang, N. Matan, and N. Matan, "Nutritional composition of the farmed edible bird's nest (Collocalia fuciphaga) in Thailand," Journal of Food Composition and Analysis, vol. 31, no. 1, pp. 41-45, 2013.

[7] N. M. Z. Huda, A. B. Z. Zuki, K. Azhar et al., "Proximate, elemental and fatty acid analysis of pre-processed edible birds' nest (Aerodramus fuciphagus): a comparison between regions and type of nest," Journal of Food Technology, vol. 6, no. 1, pp. 39-44, 2008.

[8] M. Paydar, Y. L. Wong, W. F. Wong, O. A. A. Hamdi, N. A. Kadir, and C. Y. Looi, "Prevalence of nitrite and nitrate contents and its effect on edible bird nest's color," Journal of Food Science, vol. 78, no. 12, pp. 1940-1947, 2013.

[9] M. C. Quek, N. L. Chin, Y. A. Yusof, S. W. Tan, and C. L. Law, "Preliminary nitrite, nitrate and colour analysis of Malaysian edible bird's nest," Information Processing in Agriculture, vol. 2, no. 1, pp. 1-5, 2015.

[10] J. X. J. Chen, P. K. C. Lim, S. F. Wong, and J. W. Mak, "Determination of the presence and levels of heavy metals and other elements in raw and commercial edible bird nests," Malaysian Journal of Nutrition, vol. 20, no. 3, pp. 377-391, 2014.

[11] J. X. J. Chen, S. F. Wong, P. K. C. Lim, and J. W. Mak, "Culture and molecular identification of fungal contaminants in edible bird nests," Food Additives \& Contaminants: Part A, vol. 32, no. 12, pp. 2138-2147, 2015.
[12] S. C. Larsson, N. Orsini, and A. Wolk, "Processed meat consumption and stomach cancer risk: a meta-analysis," JNCI: Journal of the National Cancer Institute, vol. 98, no. 15, pp. 1078-1087, 2006.

[13] A. Fox, Microbiology and Immunology Online, Bacteriology: Enterobacteriaceae, Vibrio, Campylobacter and Helicobacter, Chapter 11, University of South Carolina, Columbia, SC, USA, 2016, http://www.microbiologybook.org/fox/enterobact.htm.

[14] A. R. Aswir and N. W. M. Wan, "Effect of edible bird's nest on cell proliferation and tumor necrosis factor-alpha (TNF- $\alpha$ ) release in vitro," International Food Research Journal, vol. 18, no. 3, pp. 1073-1077, 2011.

[15] A. Haghani, P. Mehrbod, N. Safi et al., "In vitro and in vivo mechanism of immunomodulatory and antiviral activity of edible bird's nest (EBN) against influenza A virus (IAV) infection," Journal of Ethnopharmacology, vol. 185, pp. 327340, 2016.

[16] R. Ideris, G. Li, X. J. Kong et al., "The improvement effects of edible bird's nest on proliferation and activation of B lymphocyte and its antagonistic effects on immune-suppression induced by cyclophosphamide," Drug Design, Development and Therapy, vol. 10, pp. 371-381, 2016.

[17] S. Careena, D. Sani, S. N. Tan et al., "Effect of edible bird's nest extract on lipopolysaccharide-induced impairment of learning and memory in wistar rats," Evidence-Based Complementary and Alternative Medicine, vol. 2018, pp. 1-7, 2018.

[18] Y. C. Kong, W. M. Keung, T. T. Yip, K. M. Ko, S. W. Tsao, and M. H. Ng, "Evidence that epidermal growth factor is present in swiftlet's (Collocalia) nest," Comparative Biochemistry and Physiology Part B: Comparative Biochemistry, vol. 87, no. 2, pp. 221-226, 1987.

[19] F. C. Ma and D. C. Liu, "Extraction and determination of hormones in the edible bird's nest," Asian Journal of Chemistry, vol. 24, no. 1, pp. 117-120, 2012.

[20] M. Yang, S.-H. Cheung, S. C. Li, and H.-Y. Cheung, "Establishment of a holistic and scientific protocol for the authentication and quality assurance of edible bird's nest," Food Chemistry, vol. 151, pp. 271-278, 2014.

[21] R. I. Nicholson, J. M. Gee, and M. E. Harper, "EGFR and cancer prognosis," European Journal of Cancer, vol. 37, no. 4, pp. S9-S15, 2001.

[22] Association of Official Analytical Chemists, Official Methods of Analysis, Association of Official Analytical Chemistry, Washington, DC, USA, 17th edition, 2005.

[23] Standard Association of Australia, Australian Standard AS1766, Part 2, Section 5, 1991.

[24] Standard Association of Australia, Australian Standard AS1766, Part 2, Section 1, 1991.

[25] Standard Association of Australia, Australian Standard AS1766, Part 2, Section 3, 1987.

[26] Bacteriological Analytical Manual, Revision A, AOAC International, 8th edition, 1998.

[27] D. L. M. Goh, K. Y. Chua, F. T. Chew et al., "Immunochemical characterization of edible bird's nest allergens," Journal of Allergy and Clinical Immunology, vol. 107, no. 6, pp. 10821088, 2001.

[28] H. Li and X. Fan, "Analysis of sialic acids in Chinese conventional foods by HPLC-FLD," Open Journal of Preventive Medicine, vol. 4, no. 2, pp. 57-63, 2014.

[29] Y. Lu, D. B. Han, J. Y. Wang, D. R. Wang, R. Y. He, and L. X. Han, "Study on the main ingredients of the three species of edible swift's nest of Yunnan province," Zoological Research, vol. 16, no. 4, pp. 385-391, 1995. 
[30] P. P.-H. But, R.-W. Jiang, and P.-C. Shaw, "Edible bird's nestshow do the red ones get red?," Journal of Ethnopharmacology, vol. 145, no. 1, pp. 378-380, 2013.

[31] E. Pehlivan, A. M. Özkan, S. Dinç, and S. Parlayici, "Adsorption of $\mathrm{Cu}^{2+}$ and $\mathrm{Pb}^{2+}$ ion on dolomite powder," Journal of Hazardous Materials, vol. 167, no. 1-3, pp. 1044-1049, 2009.

[32] K. B. Roh, J. Lee, Y. S. Kim et al., "Mechanisms of edible bird's nest extract-induced proliferation of human adipose-derived stem cells," Evidence-Based Complementary and Alternative Medicine, vol. 2012, Article ID 797520, 2011. 


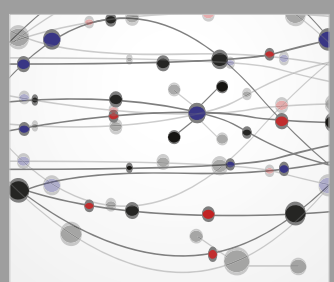

The Scientific World Journal
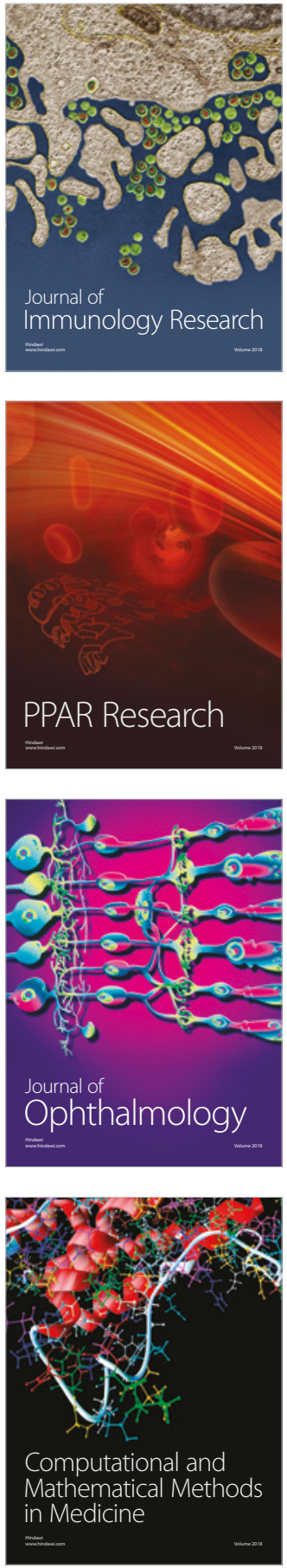

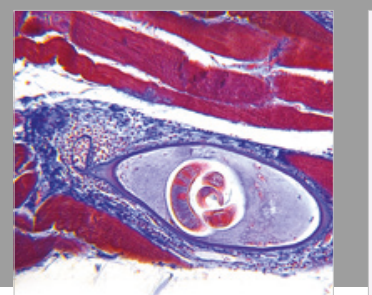

Gastroenterology Research and Practice

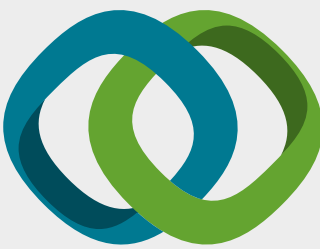

\section{Hindawi}

Submit your manuscripts at

www.hindawi.com
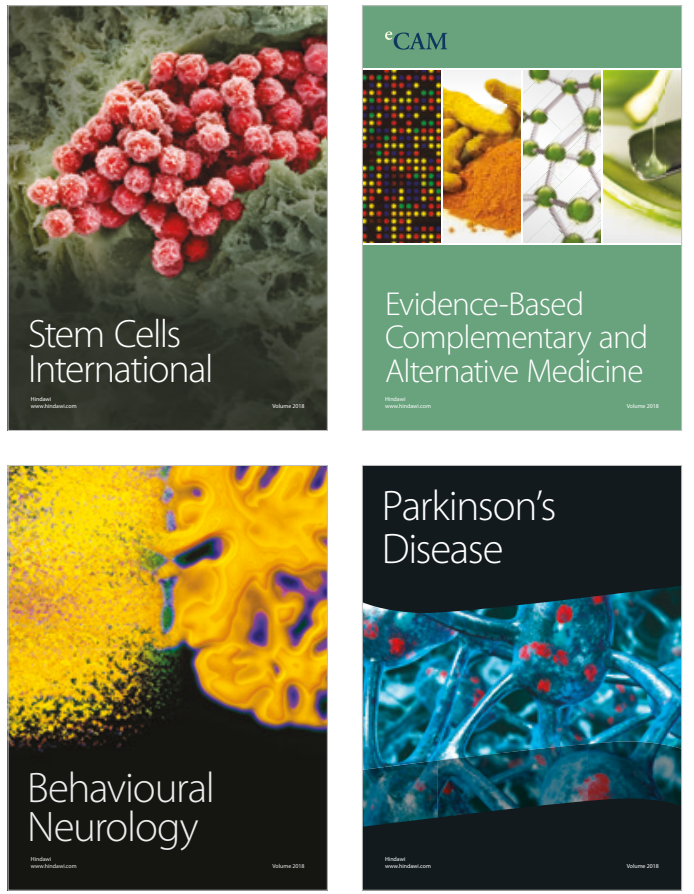

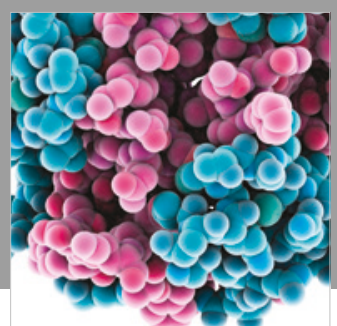

ournal of

Diabetes Research

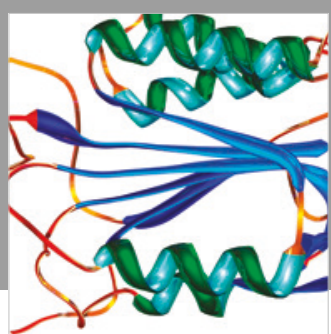

Disease Markers
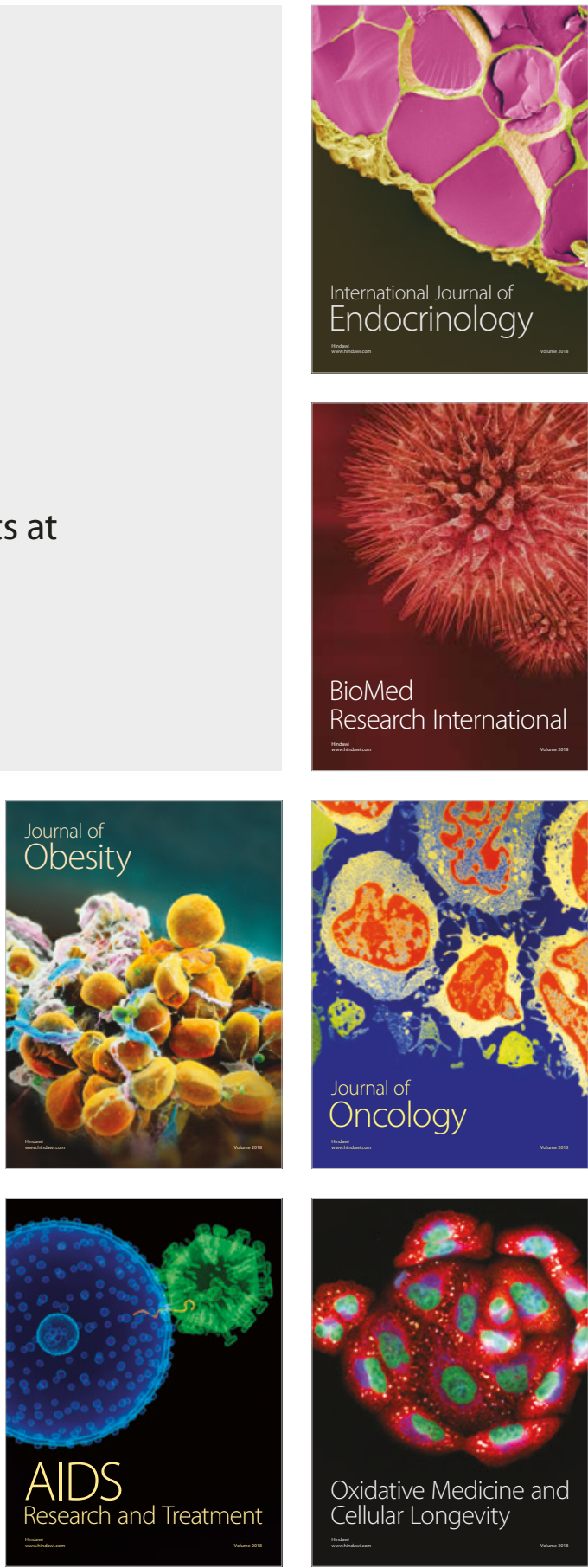